\title{
LANDSCAPE, SOCIAL DARWTNISM AND THE CULTURAL ROOTS OF SOUTH AFRICAN RACIAL IDEOLOGY
}

\author{
by
}

Paul Rich

In this essay I shall be seeking to examine the development of white racial ideology in South Africa in the context of changing imagery of landscape and Social Darwinist notions of race fitness. The main period covered will be from the 1870s up to the attainment of Union in 1910, though other periods will be referred to. The discussion is part of a wider piece of research in which I am working and the conclusions are necessarily tentative. (1)

The significance of "landscape" in South African history has tended to be overlooked by most historians, unlike their American counterparts, though it can be argued that the symbolic associations derived from images of different sorts of landscape on the South African terrain are a crucial component of the more systematized set of racial ideologies developed in the twentieth century accompanying urbanization, industrialization and the rise of political nationalisms. Within the more orthodox framework of "liberal" historiography, landscape tended to be subsumed within a wider, if somewhat static notion of the "frontier". Thus, within this view, landscape was a mere backdrop to the more epic "racial" encounters between African tribes, Boer trekkers and British colonial settlers from which the racial ideas in South African history were seen to accrue. If landscape did have a role, it was more in terms of its historical associations with this frontier period rather than as a continuing and active cultural symbol during a period of industrialization. In essence, liberal historians drew a sharp distinction between city and countryside, with the latter being seen as the terrain in which racial ideology was generated and as the source for what was seen as an anachronistic pre-industrial hangover in an otherwise modemizing society. This view reached its apogee in The Oxford History of South Africa and was sharply attacked by the neoMarxist revisionist school for overlooking the structural determinants within the urbanizing and industrial context for the reformulation of racial ideology, especially in so far as this could both sustain and reproduce capitalist relations of production.

While the revisionist school, on the other hand, has been the source for much valuable social and urban history in South Africa over the past decade, it too has overlooked the role of landscape. In contrast to the liberal emphasis on the frontier, the revisionists in many respects went to the opposite extreme in emphasizing the centrality of both capitalist industrialization and urbanization. As the physical landscape started to be be remade on the basis of mine dumps, compounds, shebeens, weal thy white suburbs and segregated townships, so, it appeared, did the actual set of ideological concepts forming the mental landscape of the society. The revisionist work on the formulation of segregationist ideology in the late nineteenth and early twentieth centuries, for instance, emphasized the 
conscious process of ideological reformulation taking place. Using the Gramscian notion of ideological entrepreneurship, particular emphasis was placed on the writings of the Milner kindergarten in the Transvaal after the Anglo-Boer War and such figures as Howard Pim, Lionel Curtis and F. W. Bell. (2) Much of this work started out from the seminal paper of Harold Wolpe emphasizing the close interrelationship between the need by South African mining capital for the super-exploitation of African labour power, the subsistence base of the African reserve economies which could permit this on the basis of the migrant labour system, and the ideology of segregation which underpinned the operation of the whole system. (3) It was thus the ideological construction of "segregation" which drove the system onwards during the first half of the twentieth century, though, as the subsistence base of the reserves declined, the need for increasing state authoritarianism in a situation of growing class struggle necessitated the reformulation into the ideology of apartheid. The methodology of this approach thus hinged considerably upon the centrality of periods of rapid change and political hiatus rather than the continuity of ideological images and symbols. As a sociological theory centred around notions of modes of production and their respective articulation, it was not in essence an historical theory, and the historical evidence has tended to be used ex post facto to rationalize the preexisting theoretical construct. Thus, in grasping the notion of ideological change and reformulation, the revisionists tended to be drawn to those ideological entrepreneurs whose thought processes were most in tune with the pace of change of an economic system geared to the interests of mining capital. Belinda Bozzoli, for example, in a full-length study of the ideology of the South African ruling class between 1890 and 1933, looked in particular at "mining ideologists" such as compound managers, whom she saw as successfully reformulating the pre-industrial frontier ideology to suit their own political and economic purposes. Thus the frontier tended to become reduced to that of a periphery which had no characteristics except in relation to mining interests.

... in discussions surrounding the problems of proletarianisation, ideologists depicted the periphery as a wholly and uniformly inferior social region. At worst, it was unalleviated savagery and barbarism; at best, "primitive" laziness and peasant stupidity. (4)

While there is much that is important in this analysis of mining ideology during a critical phase of South African history, the approach is marked by a rigid instrumentalism. The Gramscian methodology of ideological entrepreneurship overlooks the longevity that ideological symbols can have within a culture, while the focus upon systematized intellectual constructs bypasses the point that history is not a series of fresh departures and is not always being made anew. In this case, the survival of the frontier imagery is not simply surviving in the depictions of mining ideologists simply through pragmatic convenience but because it provided a set of symbolic associations within the white settler society which were already sufficiently embedded to represent a key anchoring point in any discussion of "races" or "race differences". Indeed, to this extent the significance of the frontier concept was its continuity with the pre-industrial era rather than its transmogrification into some new ideology. The search for a "total" history of South African society therefore may well need to depart from a simple insistence on continuous ideological change, for, as Fermand Braudel has reminded us, "mental frameworks" can sometimes form "prisons" of what he has termed the longue durée. (5) The important point about such an approach is that it starts from a far more intrinsically historical concept of the operation of ideology: in contrast to an a priori theory of Gramscian ideological entrepreneurship, there is the recognition that every society can be understood from a number of different time scales. Time, after all, is the essential concept of historical investigation and is frequently ill understood from a sociological standpoint, where a particular period is simply chosen to try and test some preconceived historical theory. In South African society, therefore, the mental landscape of the society can be understood historically as the product of a number of different time-spans, with their ultimate roots, as far as the imagery of race is concerned, lying in European views of race differences, though these were continually fed and reinforced by the operation of the colonial connection. 
More particularly, these racial images were embedded in a set of ideological conceptions of landscape which contained their own independent source for modernization, within a wider settler self-image. It was thus the sinking of racial imagery within this wider nexus of landscape images that accounted for the centrality of "frontier" concepts by the late nineteenth century. In many respects they can be seen as shaping the formulation of mining ideology rather than the other way round.

Racism and the Development of South African Landscape Imagery

Despite the comparative virulence of much racist ideology in South African history, the actual operation of it has to be seen in relationship to other ideological forms. "Racism" per se is an ideology rooted in a view of society divided into separate racial castes and, as a political tool for group mobilization, is comparatively weak in comparison to nationalism: it lacks, in particular, the same capacity to appeal to historical tradition, and as a "myth of the blood" is thus frequently combined with some variant of nationalism into a "racial nationalism". Only in particular historical situations, such as the Jim Crow South and Nazi Germany, has "racism" per se been carried ideologically to an almost pure form, and even then it has been linked to myths of national regeneration. (6)

Racist ideology in pre-industrial South Africa, therefore, was frequently linked with other forms of settler self-imagery in the absence of any significant nationalist group appeal. In the case of English settler intrusion from the early nineteenth century it was thus common to find images of race difference being linked to images of landscape. As in the case of American settlers on the frontier in the seventeenth and eighteenth centuries, the depiction of landscape became a central anchoring point in the re-establishment of a group identity after the cultural shock of leaving their native land to seek some new abode in a foreign place. Much of the imagery of the landscape in this state of cultural disorientation reinforced many existing conceptions of "wilderness" which had held an important place in western thought since medieval times. Given the deep-rooted JudaeoChristian conception of "wilderness" as the embodiment of evil and as a form of hell (7), the conception of it helped to emphasize the Protestant and self-defining element within the English (or frequently Scottish) colonial enterprise, as in the Easterm Cape. Just as the American settlers drew on strong biblical justification for settling the "wilderness" and establishing gardens and tending ground as agents of "civilization" (8), so the English settlers and missionaries sought a similar Christian parallel. John Campbell, for example, on his travels in the Cape saw that it was "an act of highest philanthropy, and a most exalted display of the power of Christian principles, for a missionary, from love of Jesus Christ and the souls of men, to leave European society, and retire to this gloomy wilderness, merely to do good to its scattered and miserable inhabitants". (9) This exalted conception of the self, which perhaps might be taken as an example of "the imperial self" (10), reinforced models of individualism derived from Robinson Crusoe and the Protestant tradition within English literature, stemming from John Bunyan, of counterpoising the individual with society.(11) At the same time, this individual model is linked to the idea of settling some parts of the African "wildermess" which most closely resemble the English pastoral ideal. On leaving Sondag Place on the journey to Bethelsdorp, for instance, Campbell notes that "a chain of hills runs on each side of this long valley, which by planting trees, or by cultivation, might be made one of the most beautiful spots in Africa: at present it is a lonely wildermess, having nothing to relieve the wearied eye except the variously shaped mountains". (12) Indeed, Campbell is particularly impressed by those parts of the countryside that most resemble "a nobleman's park in England", which he considered a fit place for a missionary settlement (13), whilst all the time keeping at the back of his mind the wider concept of white settlement in the country:

It fills the mind with regret to see so large and beautiful a portion of God's earth so destitute of population, and to think of its producing, year after year, provender sufficient to support millions 
of cattle, whilst only a few wild beasts roam over

it. (14)

This, however, only applies to some of the country, for a form of territorial separation has entered into Campbell's imagery of the landscape. In "Caffreland", by contrast, "wilderness" is seen as holding sway: "Caffres" are seen as frequently "lurking among bushes", while they are associated with terrain where "elephants and other wild beasts abound". (15) This pastoralized view of Africans came to hold a dominant sway over the western imperial imagination toward Africa by the middle of the nineteenth century. (16)

While the "wildermess" for Campbell reinforced a more traditional conception of both fear and loathing, there were signs of the Romantic love of wildness linked to concepts of the "picturesque". (17) In a harsh and difficult terrain, though, this more favourable view of wildermess would, as in the American case, be overridden by a more basic settler concern to eke out a living in a strange and unfamiliar environment. (18) Thomas Pringle, for example, was influenced by the Romantic upsurge in early nineteenth-century England and was a friend of Walter Scott, who helped arrange his passage with the settlers to the Easterm Cape in 1820. Pringle, too, while being impressed by the "grandeur and the grace of nature" in the Knysna Lagoon, was also strongly aware of the "air of lonesomeness and dreary wildness" of the place. (19) The harshness and "savage" nature of the terrain also led Pringle to liken the settlers to "Bunyan's pilgrims" out of the Pilgrim's Progress, though the description of the "promised land" in the Glen Lyndon location took on some of the trappings of an Arcadia:
We found the valley spilled over ... except at the extremities of its subsiding cleughs, with beautiful clumps and groves of mimosa trees, interspersed with open grassy pastures; while the river, a gurgling mountain brook, meandered placidly through the fertile meadows. Ever and anon, as we advanced up the trackless vale, some of the wild animals which were then its only inhabitants came into view, giving animation to the sequestered landscape. (20)

For the most part, though, travel accounts and missionary journals eschewed the portrayal of the landscape in South Africa in the idyllic terms of the Romantic eulogisers of the American wildermess. There was also no literary equivalent of the Emerson, Thoreau and Melville pursuit of the wild as a means of withdrawal from an urbanizing society, and it was not until the time of olive Schreiner that there was any serious depiction of landscape imagery as a means of developing a national identity. (21) However, the avoidance of the idyllic did not necessarily imply that there was no development of the landscape image in alliance with settler economic development, though this appears to have undergone a crisis in the middle years of the century. The original missionary and Protestant view exemplified by Campbell and Pringle became progressively secularized by the 1840s with the growth of the woollen industry in the Cape and the expansion of white settlement. The series of military conflicts on the Easterm Cape border and the eventual expropriation of the Kat River Settlement after the Coloured Rebellion of 1851 appear to have led, for a period at least, to a weakening of the pastoral underpinnings of the colonial racial ideology. While this period needs considerable further historical analysis, the ideas and works of the amateur geologist and poet George William Stow can be seen as reflecting a lurch towards a much more formalized "scientific" racism in the late 1840s and the 1850s. As Tony Voss has shown in a recent study, Stow, as a one-time farmer, merchant and teacher in the Cape Colony, can be located as a key opinion reflector in the Colony at the time. His pre-Darwinian use of geology to locate the African "race" within a hierarchical "great chain of being" led him to view race differences as anchored in a polygenesis concept of separate racial origins - a fashionable phenomenon in mid-nineteenth century Europe. (22) Thus, while some of Stow's poetry portrayed an idealized rural life, there was no specific South African location to this and his view of race differences is far more noteworthy for his employment of 
"scientific" metaphors derived from geology. In a defence of the English settlers during the 8th Frontier War of 1850-53, this leads to a virulent attack on the

"amakosa chiefs":

... Treacherous and fierce

Ye love to dabble in the white man's blood

Because he checked your course; and stayed your mad career

Can Day and Night agree - the tiger and the doe?

Can seas and subterranean fires conjoin -

Will not volcanoes spout; and earthquakes shake the world?

And can the savage with the man, enlightened, dwell? (23)

The periodization of this "crisis" in mid-century Cape racial ideology is of special significance, given that it has usually been seen as the time of the entrenchment of the "liberal" constitution of 1853. Stow's racism, though, possibly reflected a more fundamental settler ideological response to military and political conflict, with both African communities on the border and the Coloured population within the colony. Exactly how this ideology developed by the last quarter of the century remains an intriguing question, but a number of general themes can at this stage be pinpointed, suggesting a process of repastoralization into an ideology of race closely anchored in a modernizationist view of landscape that Leo Marx, in a seminal study of American landscape thought, has termed a "middle landscape".

\section{Social Darwinism and the Middle Landscape}

Despite the crisis in Cape racial ideology in the 1840s and 1850s, over the following two decades a profound transformation occurred, accompanying a wider phase of western technological intrusion into the African continent. (24) The opening up of diamond mining at Kimberley and gold mining in the Eastern Transvaal in the 1870s especially led to a new phase of linking machine imagery into the wilderness landscape; at the same time, the onset of Darwinian ideas enhanced the secularization of much of the colonial conception of penetration into the African terrain, to the extent that it was eventually to react upon missionary ideas by the end of the century.

Thomas Baines, for example, as both explorer and artist of the South Africa landscape, reflected the new technological intrusion in the $1870 \mathrm{~s}$ in his report on potential gold fields in the Transvaal. In the case of the Drakensberg, a romantic and ethereal image of the terrain is combined with a fiercely practical search for suitable sites for railway links:

\footnotetext{
The ridges of the Drakesberg, alive and distinct during the morning, have been gradually changing from a misty aerial blue to a deeper and deeper grey, and, as the sun declined, shewed warmed local tints, revealing the grassy slopes ... Right in our path rose the rugged masses of the Wakkerstroom hills, and it seemed evident that if the long .... highlands we had traversed were ever to be utilised as the continuation of the future colonial railways, we had now reached, or probably passed by a few miles, the point where the line must diverge to the south-west. (25)
}

At the same time, this middle landscape image of linking wild terrain with the technology of colonialism is buttressed by a concern for the fostering of white land settlement on climatically suitable upland areas, such as the watershed between the Waterburg and Zoutpansberg, where "the country can produce the finest quality of corn in abundance". (26) 
The exact mode of white settlement on this landscape remained a matter of some controversy in colonial thought throughout the 1880s and 1890s, following the defeat of the British intrusion into the Transvaal in 1881. Baines had scomed the Boers' "primitive attempts at the cultivation of the soil" and their subsistence in "primeval and patriarchal plenty" (27), and this idea of Boer seventeenth century backwardness long defined much English thought. Rider Haggard's novel Jess, for example, is centred around the idea of attempting to establish an efficient class of English gentry in the Transvaal and the ultimate failure of this after the British defeat in the first Boer war. Not all British travellers shared this view, though, and for J. A. Froude, for example, the Boers represented a strong parallel to hardworking Scotch farmers of two hundred years ago and, despite their "hatred of the English", were "civil and hospitable to English traditions and sportsmen". (28) With the advent of goldmining on the Witwatersrand, however, newer forces favouring commercialized agriculture came into play and, as Stanley Trapido has recently shown in the case of Lewis' and Mark' 'Vereeniging Estates, land companies could sustain the rise of a new corporate gentry with shooting rights given to those in the company's favour. The culmination of this ideology of land settlement was the Milnerite definition in the wake of the Anglo-Boer War and the gentrified depiction of the Transvaal veld given by the would-be South African laird, John Buchan. Once again, the conception of wilderness derived from Bunyan is applied to the landscape, in this case the "great pastoral uplands of Rustenburg" and the vista to the far north-west, which is "not unl.ike a child's conception of the landscape of Bunyan, a road running straight through a mystical green country, with the hilltops of the Delectable Mountains to cheer the pilgrim". (30)

The significance of Buchan's view of the Transvaal landscape, however, lay in its strong particularization between the high veld areas which were seen as suitable for white land settlement and the low veld areas which he saw as having a "curious savagery". (31) In his novel Prester John (1910), an African insurrection is seen as a war between the white "plateau". and the African "plains", introducing a strong set of symbolic associations to underpin the emerging ideology of territorial segregation in the post-Union white settler state in South Africa. There was, though, a probable imperial conception to this, given the growing British fear of proletarian upsurge in the colonial empire which, in the case of Australia, had seen a rising colonial nationalism in the $1890 \mathrm{~s}$, identifying strongly with images from the bush interior. (32) Such proletarian nationalism was the first major challenge to British establishment hegemony, preceding by several decades the indigenous upsurge in Britain post-1945. Thus, there were additional reasons for Buchan to pour scorm on the idea of eulogizing the bush veld in the manner of the Australian poet, who "sings of the bush in the rococo accents of Fleet Street" (33), and to seek to develop a gentry ideology as a unifying force behind white settler ideology in South Africa. As Percy Fitzpatrick's story, Jock of the Bushveld, written after Buchan's departure from South Africa, indicates, this image did not totally capture settler imagery in South Africa, though the bushveld here is seen strongly in terms of a romantic playground, with games being played on the itinerant Africans crossing from Mozambique on their way to the gold mines. (34)

The gentrified view of the South African landscape, however, can be seen as strongly shaping the white South African landscape image in the years after Union. More particularly, it acted as a crucial cultural symbol in widening and popularizing Social Darwinist ideas on varying capacities for race fitness, with different territorial areas allocated for different racial groups according to their perceived relationship to landscape and agriculture. Social Darwinism thus secularized the earlier missionary view of the white Christian duty to open up the wildermess. In the case of Dudley Kidd's The Essential Kaffir, Africans were suitably placed in their "natural" condition in their respective reserve areas, for, "as highly evolved animals", their "nature is well rooted in red earth". (35) This static conception of Africans' pastoral life, and their evolutionary unfitness for the ways of the city, acted as a powerful ideological fillip for urban segregationism and the Stallardist precept, embodied in the 1923 Natives (Urban Areas) Act, that Africans should be in cities only to minister to white labour needs. Furthermore, from the early twentieth century it contributed to some segregation by missionaries, whose own civilizing impetus, from the nineteenth century, seemed increasingly attenuated in the face of industrialization and urbanization. (36) 
Finally, the gentrified and particularistic view of landscape contributed to the white segregationist attack on the liberal tradition of racial identity from the nineteenth century. Olive Schreiner's Thoughts on South Africa represented a last, desperate plea for a unified view of South African landscape as a nationalistic reaction to the perceived imperial rape of the land. Furthermore, Schreiner's antiDarwinism and feminism led her to genderize the landscape as a female cultural resource opposed to a male-defined imperialism that oppressed both blacks and women. Schreiner's image of South Africa's "certain colossal plenitude, a certain large freedom in all its natural proportions" (37), represented a view of South African landscape that became markedly eclipsed in the years after the first world war. While in South Africa territorial segregation began to be institutionalized, on the international plane feminism suffered a marked defeat with the onset of Freudianism. (38) The new genre in literature was set by the pursuit of rural gentility, as in Sarah Gertrude Millin's Mary Glenn, and it was not for several decades and with the upsurge of newer writing in the wake of Nadine Gordimer's The Conservationist (1974) that a reassessment of South African landscape began to take place.

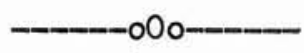

Notes

(1) The title of this is "Landscape, Literature and Racial Imagery in South Africa".

(2) See in particular the unpublished paper by Martin Legassick "The Making of South African 'Native Policy', 1903-1923: the origins of segregation", London, ICS (mimeo), 1972.

(3) Harold Wolpe, "Capitalism and Cheap Labour Power in South Africa: from segregation to apartheid", Economy and Society, XIV, November 1972, pp 425-56.

(4) Belinda Bozzoil, the Political Nature of a Ruling Class: capital and ideology in South Africa, 1890-1933 (London, 1981), p 54.

(5) Fernand Braudel, On History (London, 1980), p 31.

(6) For an important discussion on the rise of racism and nationalism in the first half of the nineteenth century, see Michael D Biddiss, "Myths of the Blood: European racist ideology, 1850-1945", Patterns of Prejudice, VII, September/ October 1975, pp 11-19. See also Anthony D Smith, Nationalism in the Twentieth Century (Oxford, 1979), especially pp 87-103. For the view that Nazi racism was an historical instance of a pure racist ideology carried to an unchecked extreme through the control of the state apparatus by a group of "unchecked desperadoes", see Heinrich August Winkler, "German Society, Hitler and the Illusion of Restoration, 1930-33" in George C Mosse (ed), International Fascism: new theories and new approaches (London and Beverly Hills, 1979).

(7) Roderick Nash, Wilderness and the American Mind (New Haven and London, 1967), pp 8-9.

(8) Ibid., pp 13-25; Henry Nash Smith, Virgin Land: the American West as symbol and myth (Cambridge, 1950); Leo Marx, The Machine in the Garden: technology and the pastoral ideal in America (London, 1964).

(9) John Campbell, Travels in South Africa (Cape Town, 1974) (I ed 1815), p 31.

(10) Quentin Anderson, The Imperial Self: an essay in American literary and cultural history (New York, 1971), has defined this term in the context of the work of Emerson, Whitman and Henry James as one of "profound extrasocial commitment: their imaginative work ignores, elides, or transforms history, politics, heterosexuality, the hope for purposive change. They avoid or omit any acknowledgement that our experience has stubborm and irreducible elements which we cannot in a lifetime either alter or understand" ( $p$ viii).

(11) Campbell, op. cit., p 31. 
(12) Tbid., p 57.

(13) Ibid., pp 100, 117.

(14) Ibid., p 153.

(15) Tbid., pp 103, 118.

(16) See in particular H Alan C Cairns, Prelude to Imperialism: British reactions to Central African society, 1840-1890 (London, 1965).

(17) Campbell, op. cit., p 122. Love of the "picturesque" in eighteenth century England was an amplification of the mood of the Gothic poets and was often expressed in the erection of sham ruins. See Kenneth Clark, The Gothic Revival (London, 1962), p 67.

(18) Nash, op. cit., pp 52-53, 61.

(19) Thomas Pringle, Narrative of a Residence in South Africa in African Sketches (London, 1834), pp 123-4.

(20) Ibid., p 154.

(21) Marx, op. cit., passim; Nash, op. cit., p 67.

(22) Nancy Stepan, The Idea of Race in Science: Great Britain, 1800-1960 (London, 1982), p 36.

(23) Quoted in A E Voss, "The Hero of The Native Races: the making of a myth", paper presented at the Conference on Literature and Society in Southern Africa, University of York, September 1981, p 6.

(24) Daniel $R$ Headrick, The Tools of Empire: technology and European imperialism in the nineteenth century (New York and Oxford, 1981), p 205.

(25) Thomas Baines, The Gold Regions of South Easterm Africa (Iondon, 1877), p 115.

(26) Ibid., $p 91$.

(27) Ibid., p 106.

(28) James Anthony Froude, Two Lectures on South Africa (London, 1900), p 52.

(29) Stanley Trapido, "Putting A Plough to the Ground: a history of tenant production on the Vereeniging Estates, 1896-1920". See below, pp

(30) John Buchan, The African Colony (London, 1903), p 83; see also Tim Couzens, "The 0ld Africa of a Boy's Dream: towards interpreting Prester John", Africa Perspective, No 13, Spring 1979.

(31) Buchan, op. cit., p 88.

(32) An idea suggested by Hugh Tinker in "The British Diaspora" in The Diaspora of the British, Collected Seminar Papers No 31, University of London, Institute of Commonweal th Studies (1982), p 3.

(33) Buchan, op. cit., p 90.

(34) There was also a wilderness cult spread in South Africa by the time of the first world war by authors like W C Scully, based on desert travel narratives. See, for example, the interesting Lodges in the Wildermess (London, 1915). This image of the desert as a romantic retreat from a materialist urban civilization should be contrasted, though, with the image of the material hardship it implied, especially for poorer white settlers such as the Boers seeking to cross the Kalahari desert to Namibia after the Boer War, in Hermann Bosmann's story "The Rooinek". "The particular bit of Africa we lived in is just one waste of sands, sands and sands again", wrote one settler, "with the undiluted sunshine turmed on full above them, seventeen hours out of twentyfour." (Crosbie Garstin, The Sunshine Settlers [London, 1918].)

(35) Dudley Kidd, The Essential Kaffir (London, 1904), p 62.

(36) See, for example, Godfrey Callaway, Sketches of Kaffir Life (London, 1905), pp 4, 101.

(37) Olive Schreiner, Thoughts on South Africa (London, 1923), pp 49-50.

(38) See the seminal paper by Flavia Alaya, "Victorian Science and the 'Genius' of Woman", Journal of the History of Ideas, XXXVIII, No 2, April-June 1977, especially pp 279-80, for this argument. 